\title{
Lack of polymorphism in the oocyte derived growth factor (GDF9) gene in the Shal breed of sheep
}

\author{
M. Ghaffari ${ }^{1}$, A. Nejati-Javaremi ${ }^{1 \#}$ and G. Rahimi-Mianji ${ }^{2}$ \\ ${ }^{1}$ Department of Animal Science, Faculty of Agricultural Sciences, University of Tehran, Iran \\ ${ }^{2}$ Laboratory for Molecular Genetics and Animal Biotechnology, Sari Agricultural Sciences and Natural \\ Resources University, Iran
}

\begin{abstract}
The families of TGF- $\beta$ proteins are the most important growth factors in the ovary for growth and differentiation of early ovarian follicles. Three related oocyte-derived members of the transforming growth factor- $\beta$ superfamily, namely GDF9, BMP15 and BMPR-IB have been shown to be essential for follicular growth and ovulation. The aim of the present study was to detect the incidence of mutation in exon two of GDF9 as a major gene in the Shal sheep breed. Blood samples were collected from 239 sheep and genomic DNA was extracted using the modified salting-out method. The quantity and quality of extracted DNA was examined using spectrophotometery and gel electrophoresis, respectively. A fragment with the size of $139 \mathrm{bp}$ from exon two of GDF9 gene $\left(F e c \mathrm{G}^{\mathrm{H}}\right)$ was amplified using polymerase chain reaction (PCR) with a pair of specific primers. The amplified PCR products were digested with DdeI restriction enzyme. In the presence of mutations at this locus, the DdeI enzyme cannot recognize the restriction site. However, in the absence of mutations, the enzyme recognizes one restriction site and divides the amplified fragment into two fragments of 31 and $108 \mathrm{bp}$. In the present study only the wild type alleles were detected and all the samples showed the AA genotype. The analysis of polymorphism for GDF9 $\left(F e c \mathrm{G}^{\mathrm{H}}\right)$ loci in Shal sheep indicates that the genetic factor responsible for twinning or multiple lambing rates is not related to reported mutated alleles at the GDF9 major gene in this breed. Therefore, we should attempt to detect other SNP for the GDF9 gene and/or other loci responsible for twining rate in this breed.
\end{abstract}

Keywords: Sheep, Shal breed, twinning, GDF9, PCR-RFLP

${ }^{\#}$ Corresponding author. E-mail: javaremi@ut.ac.ir

\section{Introduction}

Improvement of reproductive traits in livestock species has become of increasing interest, especially in sheep, where small increases in litter size can equal large gains in profit. Genetic improvement of reproductive traits has traditionally been restricted to use of quantitative genetic methods but gain has been limited when using these methods. Recently improvement in molecular genetics provided that the major genes associated with reproduction can be utilized in breeding through marker-assisted selection (MAS). Reproductive traits are often suggested as prime targets for MAS for their low heritability and the fact that the trait can be measured only in one sex. Ovulation rate (i.e. the number of mature oocytes released during one reproductive cycle) in mammals is determined by a complex exchange of hormone signals between the pituitary gland and the ovary, and by a localized exchange of hormones within ovarian follicles between the oocyte and its adjacent somatic cells (Galloway et al., 2000; Eppig, 2001). Many mammals including primates, goats, cattle, deer and possums normally have an ovulation rate of one or sometimes two whereas other mammals such as rats, mice, hamsters, cats, dogs and pigs have ovulation rates that vary between four and 15 (McNatty et al., 2005).

Genetic variation in ovulation rate in sheep has been widely documented and the evidence shows substantial differences among breeds and in a number of cases exceptional variations within breeds/strains (Bindon et al., 1996). The latter phenomenon has been explained by segregation of a major gene with a large effect on ovarian function. This hypothesis provided an explanation for high prolificacy of Booroola sheep (Davis et al., 1982; Piper et al., 1982). Subsequently, putative major genes were invoked to explain the increased litter size and/or ovulation rate in a variety of breeds/strains, including Inverdale (Davis et al., 1991), Cambridge (Hanrahan et al., 2004), Thoka (Jonmundsson et el., 1985), Javanese (Bradford et al., 
1986), Olkuska (Radomska et al., 1988), Belclare (Hanrahan et al., 1991), Lacaune (Bodin et al., 1998) and Woodlands (Davis et al., 2001) sheep breeds.

Growth differentiation factor 9 (GDF9) is a growth factor and a member of the transforming growth factor $\beta$ superfamily that is secreted by oocytes in growing ovarian follicles, which is essential for growth and differentiation of early ovarian follicles (McPherron et al., 1993). GDF9 was reported to be expressed exclusively in the ovary, specifically in the oocyte in mice (McGrath et al., 1995; Dube et al., 1998; Lan et al., 2003), rats (Vitt et al., 2000), sheep (Bodensteiner et al., 1999; Juengel et al., 2002), cattle (Bodensteiner et al., 1999) and the human (Vitt et al., 2000). The structure of the GDF9 gene had been reported in rats (Jaatinen et al., 1999) and sheep (Bodensteiner et al., 1999). Female mice lacking GDF9 were infertile due to a block in folliculogenesis at the primary follicle stage (Dong et al., 1996; Carabatsos et al., 1998).

Bodensteiner et al. (1999) reported the nucleotide sequence of the ovine GDF9 gene (GenBank accession number AF078545). Like the human and mouse genes, ovine GDF9 spans approximately $2.5 \mathrm{~kb}$ and contains two exons and one intron. Exon 1 spans $397 \mathrm{bp}$ and encodes for amino acids 1-134, while exon 2 spans $968 \mathrm{bp}$ and encodes for amino acids 135-456. The single intron spans $1126 \mathrm{bp}$. Bodensteiner et al. (2000) reported that this was the first time that the GDF9 mRNA expression was localized exclusively to oocytes of foetal sheep at day 135 of gestation. Sadighi et al. $(1998 ; 2002)$ mapped the GDF9 gene to ovine chromosome 5. Juengel et al. (2004) reported that short-term immunization against GDF9 peptide resulted in an increase in ovulation rate with no apparent detrimental effects on fertilization of released oocytes, the ability of fertilized oocytes to undergo normal foetal development, or the ability of the immunized ewes to carry a pregnancy to term. Cambridge and Belclare are prolific sheep breeds, the origins of which involved selecting ewes with exceptionally high litter size records from commercial flocks. Hanrahan et al. (2004) reported a mutation (S395F) in the GDF9 gene that was associated with both increased ovulation rate in heterozygous carriers and sterility in homozygous carriers in Cambridge and Belclare sheep. The aim of this study was to investigate the presence of polymorphism in GDF9 and its possible association with litter size in the Shal sheep breed.

\section{Material and Methods}

The origin of the Shal sheep is the Qazvin Province of Iran and it is kept mainly to produce lamb meat. When receiving creep feeding, the lambs have an average daily gain of about $250 \mathrm{~g}$. Compared to other native breeds of sheep in Iran this breed has a higher average twinning rate and also better feed conversion ratio with higher dressing percentage. The average weight for the rams is $82 \mathrm{~kg}$ and the ewes, $61 \mathrm{~kg}$. The ability to adapt to different environmental circumstances is a desirable characteristic of this breed. Its reproduction season is scattered across the year and it may be bred in both fall and spring (Ghaffari et al., 2009).

Whole blood samples $(5 \mathrm{~mL})$ were collected in vacutainer tubes containing EDTA $(1 \mathrm{mg} / \mathrm{mL})$ from 239 Shal sheep in the Qazvin province. The blood samples were transferred in dry ice to the laboratory and stored at $-20{ }^{\circ} \mathrm{C}$ pending assays. DNA was extracted using a modified salting out procedure (Miller $e t$ al., 1988) and the purity and concentration of DNA samples were estimated using UV-visible range Spectrophotometer. DNA concentration was adjusted to $50 \mathrm{ng} / \mu \mathrm{L}$ before PCR amplification. All the DNA samples had the 260/280 OD ratios in the range of 1.8 to 2, indicating high purity. DNA was also examined by loading samples on $0.8 \%$ agarose gel and visualizing the band under gel documentation system (Bio RAD).

Primers were synthesized by the Metabion Company (Metabion International AG Company, Germany) based on the sequences described by Hanrahan et al. (2004). The forced PCR-RFLP was carried out by introduction of a synthetic restriction site, since there was no DdeI restriction site on the amplified fragment. Genomic DNA was amplified using DdeIR: 5'-CTTTAGTCAGCTGAAGTGGGACAAC-3' and DdeIF: 5'-ATGGATGATGTTCTGCACCATGGTGTGAACCTG A-3' to amplify a 139-bp PCR product at $72{ }^{\circ} \mathrm{C}$. The PCR primer introduces the DdeI restriction site in GDF9 mutant copies $\left(F e c G^{H}\right)$ but not in non-carrier individuals. The wild-type strand was cleaved with $D d e I$. The amplification procedure was carried out based on the method described by Davis et al. (2002). In brief, a total volume of $25 \mu \mathrm{L}$ of each PCR reaction contained $1.5 \mu \mathrm{L}$ of genomic DNA (10 ng/ $\mu \mathrm{L}), 3 \mathrm{mM}$ of $\mathrm{MgCl} 2,0.25 \mu \mathrm{L}$ each of forward and reverse primers (10 pmol each), $0.2 \mu \mathrm{L}$ of dNTPs $(200 \mu \mathrm{M}$ each), 1 unit of Taq DNA polymerase (CinnaGen, Iran) and $1 \mathrm{X}$ PCR buffer $(10 \mathrm{mM}$ Tris, $50 \mathrm{mM} \mathrm{KCl}, 0.1 \%$ gelatin, $\mathrm{pH}$. 8.4). The 
amplification was carried out using 35 cycles at $94{ }^{\circ} \mathrm{C}$ for $30 \mathrm{~s}, 62{ }^{\circ} \mathrm{C}$ for $40 \mathrm{~s}$, and $72{ }^{\circ} \mathrm{C}$ for $30 \mathrm{~s}$ followed by $72{ }^{\circ} \mathrm{C}$ for $4 \mathrm{~min}$. The PCR products were digested with $\mathrm{DdeI}$ over night at $37^{\circ} \mathrm{C}$. The resulting products were separated by electrophoresis on a $3 \%$ agarose gel and visualized with ethidium bromide under a gel documentation system.

The PCR product of the exon 2 of GDF9 $\left(\mathrm{FecG}^{\mathrm{H}}\right)$ gene produced a $139 \mathrm{bp}$ band. After digestion with $D d e$ I, the exon 2 of GDF9 gene homozygous carriers should produce a $139 \mathrm{bp}(\mathrm{BB})$, the non-carrier should produce both 108 and 31 bp (AA), whereas heterozygotes should produce 31, 108 and 139 bp bands (AB).

\section{Results}

A total of 239 individuals from the Shal breed of sheep were genotyped with the forced PCR-RFLP approach. The electrophoretic profiles of RFLP analysis from GDF9 gene are shown in Figure 1. Generally, between 20 to $35 \%$ of twinning is observed in flocks of the Shal sheep breed. The results show that no polymorphism in exon 2 of GDF9 gene exists in the typed samples and all individuals had the wild type (AA) genotype (Table 1).

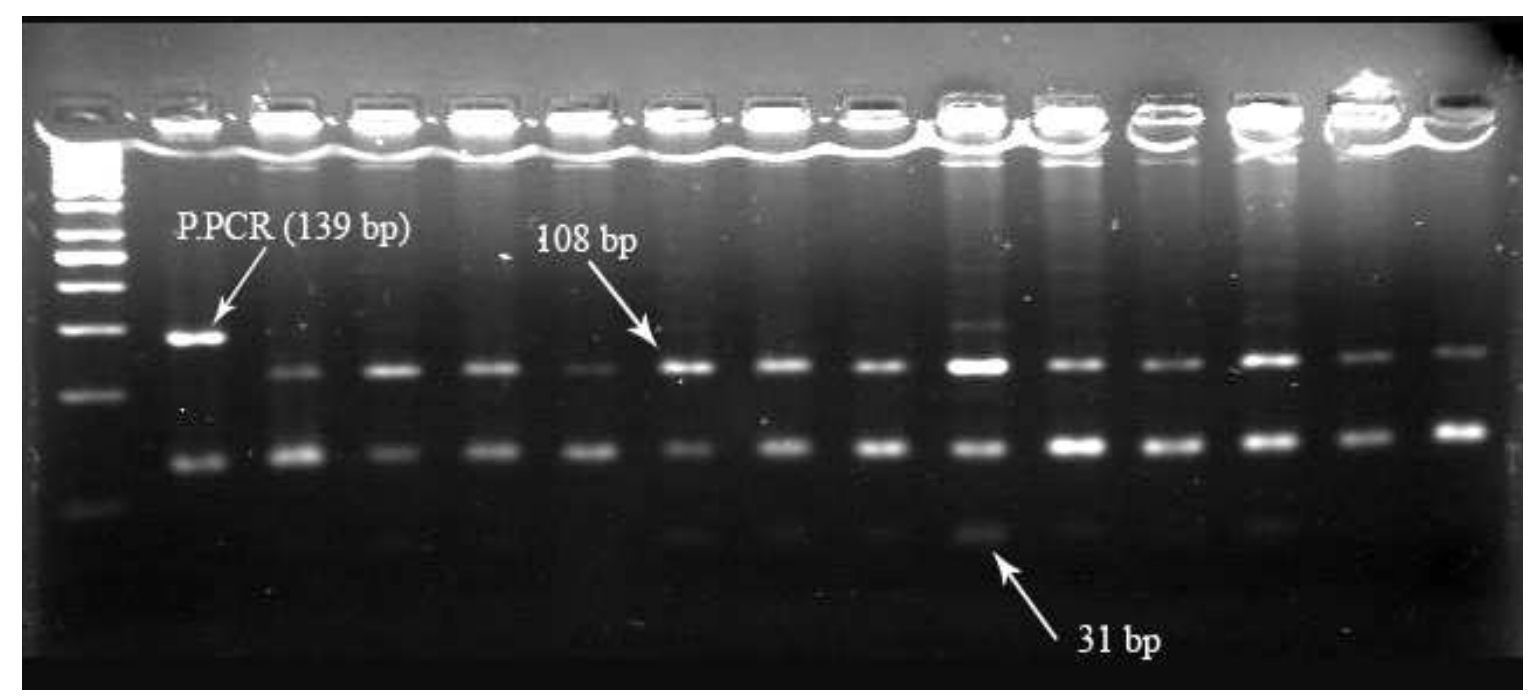

Figure 1 DdeI PCR-RFLP analysis of GDF9 $\left(\mathrm{FecG}^{\mathrm{H}}\right)$ gene in Shal sheep breed.

Table 1 Gene and genotype frequencies for exon 2 of GDF9 $\left(F e c \mathrm{G}^{\mathrm{H}}\right)$ gene in Shal sheep breed

\begin{tabular}{ccccc}
\hline \multicolumn{2}{l}{ Gene frequency } & \multicolumn{4}{c}{ Genotype frequency } \\
\hline $\mathrm{A}$ & $\mathrm{B}$ & $\mathrm{AA}$ & $\mathrm{AB}$ & $\mathrm{BB}$ \\
\hline 1 & 0 & 1 & 0 & 0 \\
\hline
\end{tabular}

\section{Discussion}

RFLP is a rapid, simple and exact technique for single nucleotide polymorphism (SNP) genotyping. After a forced restriction site was introduced into one of the primers, the PCR product contained a certain restriction enzyme site. This forced PCR RFLP approach has been used previously to genotype prolific sheep (Souza et al., 2001; Davis et al., 2002; Kumar et al., 2006; Guan et al., 2007) and pigs (Kim et al., 2003) to decide whether they had the same mutation as FecB in Booroola Merino sheep.

In our experiment, a forced PCR-RFLP approach was used to detect the genotype based on the method described by Souza et al. (2001) and Davis et al. (2002). However, in the present study we have used agarose gel instead of polyacrylamide in the electrophoresis procedure. RFLP has a good repeatability and stability, 
but its results may be affected by several factors such as enzymes from different companies, time of digestion, and volume of electrophoresis and concentration of gel (Guan et al., 2007). We compared several of these factors by adding various concentrations of ingredients to select the optimal reaction conditions to maintain repeatability and veracity. Considering the results obtained in the present study (Figure 1), it is clear that the used PCR and electrophoresis strategies are suitable for detection of mutant copies of GDF9 gene. Detections with illegible results were repeated until the genotyping was clear.

The GDF9 gene can be considered as a possible candidate gene for increased litter size in sheep. In the present study we did not find any genetic variations within the GDF9 gene by PCR-RFLP among the members of the Shal sheep. Among many Iranian breed of sheep, the Shal breed is considered as a prolific breed and a $35 \%$ of twinning rate has been recorded in many flocks. Our samples were randomly taken from this flock and one would expect to find all possible genotypes of GDF9 if it really segregates in polymorphism.

The physiological characteristics of sheep with inactivating mutations in GDF9 have not been well characterized. Ewes with a single copy of the mutated GDF9 gene are fertile and have an increased ovulation rate (Hanrahan et al., 2004). In contrast, ewes homozygous for this mutation are infertile with primary ovarian failure. Ewes heterozygous for mutations in both GDF9 and BMP15 are fertile and the effects of these mutations on ovulation rate are additive. Hanrahan et al. (2004) reported the existence of mutation in this locus for Cambridge and Belclare sheep which was in contrast with the result of this experiment. Also, Chu et al. (2004) reported results which were not in agreement with our results.

Two oocyte-derived members of the TGF- $\beta$ superfamily that regulates fertility have been identified (Dong et al., 1996; Galloway et al., 2000; Juengel et al., 2002; Hanrahan et al., 2004). The relative importance of these members differs among species. In mice, GDF9 (Dong et al., 1996) is essential for normal follicular development and is likely involved in development of the normal cumulus cell phenotype (Dong et al., 1996). In contrast, BMP15 is not essential for normal follicular development but appears to play a role in the final maturation-ovulation of the follicle and normal oocyte health. In sheep both GDF9 and BMP15 have been shown to be essential for normal follicular growth (Galloway et al., 2000; Juengel et al., 2002; Hanrahan et al., 2004; Juengel et al., 2004). In addition, GDF9 may also be involved in luteinization of the follicle at ovulation (Juengel et al., 2002). Both GDF9 and BMP15 regulate the number of follicles ovulated in sheep, a mammal that normally has a low ovulation rate. However, no such role for either GDF9 or BMP15 has been delineated in mice, a mammal that normally has a high ovulation rate (Dong et al., 1996). Furthermore, both GDF9 and BMP15 are targets for new methods of fertility control as the number of follicles ovulating can either be suppressed or enhanced with controlled regulation of either protein (Juengel et al., 2002; 2004). In sheep, GDF9 mRNA and protein are present in germ cells during follicular formation and in oocytes of primordial follicles and at all subsequent stages of follicular growth (Bodensteiner et al., 1999; Juengel et al., 2002; 2004).

The major gene involved in the Inverdale sheep was shown to be X-linked, and it was also shown that homozygous carriers were sterile due to ovarian hypoplasia, reflecting a failure of ovarian follicles to progress beyond the primary stage of follicle development. In contrast the Booroola gene is on chromosome 6 and has an essentially additive effect on ovulation rate. The genes responsible for the Inverdale and Booroola effects were recently identified. Mutations in bone morphogenetic protein 15 (BMP15, also known as growth differentiation factor 9B) gene were associated with both increased ovulation rate in heterozygous carriers and sterility in homozygous carriers in Inverdale sheep (V31D), Hanna sheep (Q23Ter), Cambridge sheep (Q239Ter) and Belclare sheep (Q239Ter and S367I) breeds. A non-conservative substitution (Q249R) in the intracellular kinase domain of the bone morphogenetic protein receptor IB (BMPR-IB) gene was associated fully with increased ovulation rate in Booroola Merino ewes (Wilson 2001). In a previous study, the polymorphism behaviour of both Booroola (Ghaffari et al., 2009) and Inverdal (Hedayat et al., 2009) genes were analyzed as likely candidate genes influencing high prolificacy but no polymorphism has been found in the Shal sheep breed.

\section{Conclusion}

In the present study the results of PCR showed the same band pattern in all samples, implying no mutation in exon two of the GDF9 locus in Shal breed ewes. Regarding the records of twinning in this breed it is concluded that the genetic factor controlling twinning is not related to the mutation which is reported in 
the GDF9 major gene. It may be concluded that litter size in this breed is either not affected by major genes or it is possible that other SNP in the GDF9 gene or some other major genes control twinning in this breed. Further research is recommended to investigate this hypothesis.

\section{Reference}

Bindon, B.M., Piper, L.R. \& Hilliard, M.A., 1996. Reproductive physiology and endocrinology of prolific sheep. In: Prolific Sheep. Ed. Fahmy, M.H., CAB International, Wallingford, UK. pp. 453-470.

Bodin, L., Elsen, J.M., Poivey, J.P., San Cristobal-Gaudy, M., Belloc, J.P. \& Eychenne, F., 1998. Hyperprolificacy in the French Lacaune sheep breed; a possible major gene. Proc. $6^{\text {th }}$ Wrld Congr. Genetics Applied to Livestock Production; Armidale, Australia. pp. 11-14.

Bodensteiner, K.J., Clay, C.M., Moeller, C.L. \& Sawyer, H.R., 1999. Molecular cloning of the ovine growth differentiation factor 9 gene and expression of growth differentiation factor 9 in ovine and bovine ovaries. Biol. Reprod. 60, 381-386.

Bodensteiner, K.J., McNatty, K.P., Clay, C.M., Moeller, C.L. \& Sawyer, H.R., 2000. Expression of growth and differentiation factor 9 in the ovaries of fetal sheep homozygous or heterozygous for the Inverdale prolificacy gene (FecXI). Biol. Reprod. 62, 1479-1485.

Bradford, G.E., Quirke, J.F., Sitorius, P., Inounu, I., Tiesnamurti, B., Bell, F.L., Fletcher, I.C. \& Torell, D.T., 1986. Reproduction in Javanese sheep: evidence for a gene with large effect on ovulation rate and litter size. J. Anim. Sci. 63, 418-431.

Carabatsos, M.J., Elvin, J., Matzuk, M.M. \& Albertini, D.F., 1998. Characterization of oocyte and follicle development in growth differentiation factor-9-deficient mice. Develop. Biol. 204, 373-384.

Chu, M.X., Li, B.X., Wang, S.C.Ye. \& Fang, L., 2004. Association between PCR-SSCP of growth differentiation factor9 gene and high prolificacy in small tail Han sheep. Anim. Biotechnol. 15, 111-120.

Davis, G.H., Montgomery, G.W., Allison, A.J., Kelly, R.W. \& Bray, A.R., 1982. Segregation of a major gene influencing fecundity in progeny of Booroola sheep. N. Z. J. Agric. Res. 25, 525-529.

Davis, G.H., McEwan, J.C., Fennessy, P.F., Dodds, K.G. \& Farquhar, P.A., 1991. Evidence for the presence of a major gene influencing ovulation rate on the X-chromosome of sheep. Biol. Reprod. 44, 620-624.

Davis, G.H., Dodds, K.G., Wheeler. R. \& Jay, N.P., 2001. Evidence that an imprinted gene on the X chromosome increases ovulation rate in sheep. Biol. Reprod. 64, 216-221.

Davis, G.H., Galloway, S.M., Ross, I.K., Gregan, S.M., Ward, J., Nimbkar, B.V., Ghalsasi, P.M., Nimbkar, C., Gray, G.D., Subandriyo Inounu, I., Tiesnamurti, B., Martyniuk, E., Eythorsdottir, E., Mulsant, P., Lecerf, F., Hanrahan, J.P., Bradford, G.C. \& Wilson, T., 2002. DNA test in prolific sheep from eight countries provide new evidence on origin of the Booroola (FecB) mutation. Biol. Reprod. 66, 1869-874.

Dong, J.W., Albertini, D.F., Nishimori, K., Kumar, T.R., Lu, N. \& Matzuk, M.M., 1996. Growth differentiation factor 9 is required during early ovarian folliculogenesis. Nature 383, 531-535.

Dube, J.L., Wang, P., Elvin, J., Lyons, K.M., Celeste, A.J. \& Matzuk, M.M., 1998. The bone morphogenetic protein 15 gene is X-linked and expressed in oocytes. Mol. Endocrinol. 12, 1809-1817.

Eppig, J.J., 2001. Oocyte control of ovarian follicular development and function in mammals. Reproduction. $122,829-838$.

Galloway, S.M., McNatty, K.P., Cambridge, L.M., Laitinen, M.P.E., Juengel, J.L., Jokiranta, S., McLaren, R.J., Luiro, K., Dodds, K.G., Montgomery, G.W., Beattie, A.E., Davis, G.H. \& Ritvos, O., 2000. Mutations in an oocyte-derived growth factor gene (BMP15) cause increased ovulation rate and infertility in a dosage-sensitive manner. Nat. Genet. 25, 279-283.

Ghaffari, M., Nejati-Javaremi, A. \& Rahimi, G., 2009. Detection of polymorphism in BMPR-IB gene associated with twining in Shal sheep using PCR-RFLP method. Int. J. Agric. Biol. 11, 97-99.

Guan, F., Shou-ren, L., Shi, G-Q. \& Yang, L-G., 2007. Polymorphism of FecB gene in nine sheep breeds or strains and its effects on litter size, lamb growth and development. Anim. Reprod. Sci. 99, 44-52.

Hanrahan, J.P., 1991. Evidence for single gene effects on ovulation rate in the Cambridge and Belclare breeds. In: Major Genes for Reproduction in Sheep. Eds Elsen, J.M., Bodin, L. \& Thimonier, J., Paris: INRA. pp. 93-102.

Hanrahan, J.P., Gregan, S.M., Mulsant, P., Mullen, M., Davis, G.H., Powell, R. \& Galloway, S.M., 2004. Mutations in the genes for oocyte-derived growth factors GDF9 and BMP15 are associated with both 
increased ovulation rate and sterility in Cambridge and Belclare sheep (Ovis aries). Biol. Reprod. 70, 900-909.

Hedayat-Evrigh, N., Miraei-Ashtiani, S.R. \& Nejati-Javaremi, A., 2009. A study for identification Inverdale QTL marker for associated with twining in Shal sheep.The 6th national biotechnology congress of IRAN.13-15Aug. Milad tower conference hall, TEHRAN-IRAN.

Jaatinen, R., Laitinen, M.P., Vuojolainen, K., Aaltonen, J., Louhio, H., Heikinheimo, K., Lehtonen, E. \& Ritvos, O., 1999. Localization of growth differentiation factor-9 (GDF-9) mRNA and protein in rat ovaries and cDNA cloning of rat GDF-9 and its novel homolog GDF-9B. Mol. Cell. Endocrinol. 156, 189-193.

Jonmundsson, J.V. \& Adalsteinsson, S., 1985. Single genes for fecundity in Icelandic sheep. In: Genetics of Reproduction in Sheep. Eds Land, R.B. \& Robinson, D.W., London. Butterworths, UK. pp. 159-168.

Juengel, J.L., Hudson, N.L., Heath, D.A., Smith, P., Reader, K.L., Lawrence, S.B., O'Connell. A.R., Laitinen, M.P., Cranfield, M., Groome, N.P., Ritvos, O. \& McNatty, K.P., 2002. Growth differentiation factor 9 and bone morphogenetic protein 15 are essential for ovarian follicular development in sheep. Biol. Reprod. 67, 1777-1789.

Juengel, J.L., Hudson, N.L., Whiting, L. \& McNatty, K.P., 2004. Effects of immunization against bone morphogenetic protein 15 and growth differentiation factor 9 on ovulation rate, fertilization, and pregnancy in ewes. Biol. Reprod. 70, 557-561.

Kim, J.H., Song, J.H., Vallet, J.L., Rohrer, G.A., Johnson, G.A., Margaret, M.M. \& Christenson, R.K., 2003. Molecular characterization and expression of porcine bone morphogenetic protein receptor-IB in the uterus of cyclic and pregnant gilts. Biol. Reprod. 68, 735-743.

Lan, Z.J., Gu, P., Xu, X., Jackson, K.J., DeMayo, F.J., O’Malley, B.W. \& Cooney, A.J., 2003. Dependent repression of BMP-15 and GDF-9 mediates gamete regulation of female fertility. EMBO J. 22, 4070-4081.

McGrath, S.A., Esquela, A.F. \& Lee, S.J., 1995. Oocyte specific expression of growth differentiation factor 9. Mol. Endocrinol. 9, 131-36.

McNatty, K.P., Smith, P., Moore, L.G., Reader, K., Luna, S., Hanrahan, J.P., Groome, N.P., Laitinen, M., Ritvos, O. \& Juengel, J.L., 2005. Oocyte-expressed genes affecting ovulation rate. Molecular and Cell. Endocrinol. 234, 57-66.

McPherron, A.C. \& Lee, S.J., 1993. GDF-3 and GDF-9: two new members of the transforming growth factor b-superfamily containing a novel pattern of cysteines. J. Biol. Chem. 268, 3444-3449.

Miller, S.A., Dykes, D.D. \& Polesky, H.F., 1988. A simple salting out procedure for extracting DNA from human nucleated cells. Nucleic Acid Res. 16, 1215.

Piper, L.R. \& Bindon, B.M., 1982. Genetic segregation for fecundity in Booroola Merino sheep. In: Proc. World Congress on Sheep and Beef Cattle Breeding. Eds Barton, R.A., \& Smith, W.C., Palmerston North, New Zealand. pp. 395-400.

Radomska, M.J., Martyniuk, E., Klewiec, J. \& Knothe, A., 1988. Inheritance of high prolificacy of the Olkuska sheep (preliminary results). J. Agric. Sci., Finland. 60, 597-598.

Sadighi, M., Montgomery, W., Bodensteiner, K.J. \& Galloway, S.M., 1998. The growth differentiation factor 9 maps to sheep chromosome 5. Anim. Genet. 29 (Suppl. 1), 36.

Sadighi, M., Bodensteiner, K.J., Beattie, A.E. \& Galloway, S.M., 2002. Genetic mapping of ovine growth differentiation factor 9 (GDF9) to sheep chromosome 5. Anim. Genet. 33, 244-245.

Souza, C.J., MacDougall. C, MacDougall, C., Campbell, B.K., McNeilly, A.S. \& Baird, D.T., 2001. The Boorola $(\mathrm{FecB})$ phenotype is associated with a mutation in the bone morphogenetic receptor type $1 \mathrm{~B}$ (BMPR1B) gene. J. Endocrinol. 169: R1-R6.

Vitt, U.A., McGee, E.A., Hayashi, M. \& Hsueh, A.J., 2000. In vivo treatment with GDF 9 stimulates primordial and primary follicle progression and theca cell marker CYP17 in ovaries of immature rats. Endocrinol. 141, 3814-3820.

Wilson, T., Wu, X.Y., Juengel, J.L., Ross, I.K., Lumsden, J.M., Lord, E.A., Dodds, K.G., Walling, G.A., McEwan, J.C., O’Connell, A.R., McNatty, K.P. \& Montgomery, G.W., 2001. Highly prolific Booroola sheep have a mutation in the intracellular kinase domain of bone morphogenetic protein IB receptor (ALK-6) that is expressed in both oocytes and granulosa cells. Biol. Reprod. 64, 1225-1235. 